\section{THE DRIFT OF THE "ENDURANCE."}

WING to the circumstances of the time, the preparation of the preliminary reports by the men of science attached to the Weddell Sea contingent of the Shackleton Expedition has been unavoidably retarded, that of Lieut. Wordie, dealing with the oceanography, being the first to appear. ${ }^{1}$ It is a report of great interest, and that so much valuable research was accomplished on a vessel specially equipped to meet the requirements of a land expedition reflects much credit on all concerned.

Sir Ernest Shackleton, meeting with extremely unfavourable ice conditions in Weddell Sea during the summer of I9I4-I5, was unable to establish the contemplated base on Luitpold Land for his trans-Antarctic sledge journey. After a long struggle with pack, the Endurance was beset in the middle of January, I915, when only fifteen miles from the land, in lat. $76 \frac{1}{2}^{\circ} \mathrm{S}$. A strong N.E. wind that had blown for several days with gale force packed the ice tightly, so that, in spite of every effort, no progress could be made. A month later the young ice was 6 in. thick, and by the end of February, which corresponds with the month of August in the northern hemisphere, had increased to the thickness of a foot.

During the drift of the vessel until she was crushed on October 27 , the natural history of sea ice was studied and other physical observations made. These included meteorological observations every four hours by Mr. Hussey, absolute magnetic determinations at regular intervals by Mr. R. W. James, while frequent soundings and numerous series of ocean temperatures and densities were made by Lieut. Wordie. Systematic collections of plankton and other biological material from the surface to depths of more than 400 fathoms were made by Mr. Clark, the biologist, but, unfortunately, this rich material so laboriously brought together had to be abandoned when the Endurance was crushed. The greatest interest attaches to the soundings, which show that a line of relatively deep water runs south from $74^{\circ}$ to $76^{\circ} \mathrm{S}$. to the Wilhelm Barrier. Off the Luitpold coast to the east there is shallow water less than roo fathoms deep, while in a westerly direction the edge of the continental shelf is marked by depths under 250 fathoms.

The drift of the vessel lay over the continental shelf from the end of March until the end of July, so that it was possible to investigate it over a length of 270 miles from S.E. to N.W. As the ship drifted to and fro the breadth of the shelf was shown to vary from forty miles in the S.E. to seventy miles in the N.W. No idea as to the distance of the coast could be obtained, as the water did not shallow gradually in any direction. "The shelf . . . is made up of a group of terracelike levels the edges of which are steep and nearly parallel to each other along a S.W.-N.E. line." The shallow water ends abruptly a little

1 Lieut. J. M. Wordie, R.F.A., "The Drift of the Endurance Geographical Journal, vol. li., No. 4, April, I9r8.

NO. 2547 , VOL. IOI] north of lat. $73^{\frac{1}{2}} \mathrm{~S}$., long. $48^{\circ} \mathrm{W}$., the ship's position on July $3 \mathrm{I}$. A sounding made five days later, when a gale from the $\mathrm{S}$. had driven the Endurance into lat. $7 \mathrm{I}^{\circ} 42^{\prime}$ S., long. $49^{\circ} 2 \mathrm{I}^{\prime} \mathrm{W}$., gave 1146 fathoms.

This sharply defined margin of the so-called "continental" shelf seems to be characteristic of Antarctic areas, as shown by pairs of soundings a few miles apart on the Belgica, Gauss, and Scotia operating in widely separated regions. Until the Endurance sank, six other casts were made in depths between $r_{500}$ and 1900 fathoms, so that the land to the east in lat. $68^{\circ} \mathrm{S}$., reported by Morrell in 1823 , must, if it exists, be an island, and not a part of Antarctica proper. Sir James Ross had reported a "strong appearance of land" some $5^{\circ}$ due north of the position given by Morrell for his land, so that it is not improbable that in the unexplored area 165 miles broad at the narrowest point lying between the tracks of Shackleton and Filchner there may be a large island or a cluster of small ones, as suggested by Ross. There seems little doubt that Morrell did visit Weddell Sea in 1823 , and that the land he saw and coasted along to its north cape was the east coast of Graham Land previously reported by Capt. Johnson and explored by Larsen seventy years after Morrell's visit. In 1823 , as shown by Capt. Weddell's voyage a few weeks earlier, the sea south of the circle was free of pack, so that an approach from the east to the normally icecongested waters off the coast of Graham Land was quite a feasible proposition. Morrell's longitudes were, however, some $10^{\circ}$ out, owing to an error in his chronometers, so that his most southerly position on March I4, 1823, would coincide with that of the Endurance on August 25, 1915. The land reported on March i7 was evidently the southern point of Föyn coast, as determined by Larsen, while the N. cape of New South Greenland, which Morrell by dead reckoning two days later placed in lat. $62^{\circ} 4 \mathrm{I}^{\prime} \mathrm{S}$., long. $47^{\circ} 2 \mathrm{I}^{\prime}$ W., was obviously the north point of Joinville Island, $8^{\circ}$ of longitude further to the west than the position assigned by him.

Lieut. Wordie's paper contains much interesting matter, to which full justice cannot be done until the physicist and the meteorologist of the expedition have submitted their reports. A special feature of the Weddell Sea winter climate in high latitudes seems to be the absence of low temperatures. In the winter months of I9I2 the absolute minima on the Deutschland were but little lower than those at the S. Orkneys, some 500 miles to the north, and in 1915, the coldest winter of the coldest and calmest year on record at this island station, mercury never froze on the Endurance, although the vessel was from $55^{\circ}$ to 800 miles farther south. Meanwhile, it is not possible to say why this should be so. Above the cold surface cap, Barkow has shown that a relatively warm stratum of air is usually present in winter, which under certain conditions might replace the film of cold air lying over the pack ice. It is not unlikely that the seasonal march of temperature in 
the southern parts of Weddell Sea resembles that of the McMurdo Sound area in having a uniform winter temperature, instead of a sharp descent to a minimum. A steady Föhn effect of wide radius from the mountains of the Antarctic continent would explain this anomaly, as would also the incursion of relatively warm air from lower latitudes associated with incurved cyclonic N.E. winds in the eastern part of Weddell Sea. Dynamic heating in the free air, without the intervention of high land, is also within the bounds of possibility.

R. C. Mossman.

\section{NOTES.}

WhILE the British Association has suspended its annual gatherings for the last two years, the Societa italiana per il Progresso delle Scienze, the head offices of which are at 26 Via del Collegio Romano in Rome, sends us a very attractive programme of the tenth meeting, which is to be held in Pisa. on October $16-19$ under the presidency of Prof. Ferdinando Lori and the secretaryship of the indefatigable Prof. Vincenzo Reina. The success of the meetings at Rome in 1916 and at Milan and Turin in 1917 has convinced the council that it will be interpreting the wishes of the members in continuing even in war-time to maintain its activity in promoting the advancement of knowledge in the country. We notice that such subjects as mathematics, physics, chemistry, and aeronautics do not figure in the proceedings of the sections, which are to be devoted mainly to geological and mineralogical papers in Class A, biological and medical in Class B, and economical in Class $\mathrm{C}$. It is the object of the meeting to pay a large amount of attention to the study of the mineral resources of Italy. At the same time the Italian Thalassographic Commission is organising a subsection of Class B on fisheries, and is presenting an annual report, while similar reports are being presented by the Glaciological Committee and the National Commission for the Development of Scientific and Industrial Progress. The Italian Association for the Study of Building Materials is to meet in Pisa at the time of the congress. The opening meeting of the scientific gathering is to be held on Wednesday, October I6, at ro a.m., in the Aula Magna of the University, when an inaugural address will be given by Prof. Raffaello Nasini on "A Proposal for an Inventory of Italy's Mineral Wealth." In addition to the sectional meetings, nine general lectures have been arranged for the mornings of the subsequent days, while the sections will meet in the afternoons, and an excursion will talse place on the Sunday.

THE recent flight from England to Egypt, made by two R.A.F. officers and two mechanics, is an excellent example of the possibilities of aircraft with regard to long cross-country flights, and shows in an unmistakable way that the commercial use of the aeroplane after the war could be very rapidly developed. If a flight of 2000 miles can be satisfactorily made without special preparation on an ordinary service machine, it is fairly obvious that there are practically no limits to the possibilities of commercial aviation when the whole attention of designers can be given to the sub. ject, and when the excellent research facilities which we possess can be devoted to the elucidation of the new problems involved. The war has worked wonders in promoting the development of aeronautical engineering, and such feats as the above leave little doubt that one of the good after-effects of the war will be the immediate application of our greatly increased knowledge of aviation to the problems of international commerce. The question of long oversea flights is fraught with more difficulties than attend long flights overland, but there are many who think that a crossAtlantic flight is already within the bounds of possibility. The future of the aeroplane is bright with promise, and the declaration of peace will doubtless inaugurate a new era in the annals of commercial transport.

Mr. Charles Herbert Scott, whose death is announced, was born in 1860 at Lincoln, and was a member of the Institution of Mechanical Engineers. He was an authority upon linoleum manufacturing machinery, and was the patentee of many of the machines used for this process.

WE regret to note that Engineering for August 16 announces the death of Mr. Daniel Makinson Fox in his eighty-ninth year. After a varied railway experience at home and abroad, Mr. Fox acted as principal engineer of the Sao Paulo Railway in Brazil. He was a member of the Institution of Civil Engineers, and read a paper in 1870 on the Sao Paulo Railway.

THE death of Mr. Bramah Joseph Diplock, announced in the Engineer for August 16, will be regretted by many who took an interest in his wellknown invention, the pedrail. Although he had no early technical training, Mr. Diplock's insight into things mechanical was remarkable, and he held some Ioo patents in connection with transport machinery.

The Mary Kingsley medal of the Liverpool School of Tropical Medicine for research in tropical diseases has been awarded to Dr. Griffith Evans, the discoverer of the trypanosome of Surra, a disease of horses and camels of India, Burma; and the East. Dr. Evans, who was born in 1835 , has been a member of the Veterinary Department of the Army, and made his discovery in I880. He contributes on the occasion of the award of the medal an interesting autobiographical note to the Annals of Tropical Medicine and Parasitology for July (vol. xii., No. I).

Some additional information regarding the $\mathrm{Hog}$ Island shipyard has been obtained by lloyd's Register of Shipping, and appears in an article in the Engineer for August I6. The methods adopted for training the men are of interest. No skilled labour could be obtained, and a school was started, which provides daily from 300 to 400 men for the yard. A section of a ship has been built, where men are taught riveting, caulking, erecting, bolting up, pipe fitting, and any trade necessary. It is marvellous to see how quickly and how well they learn. The first ship was launched on August I4. and when it is considered that not fewer than two-thirds of the men who have built her never saw a shipyard until about six months ago, it must be admitted to be a wonderful performance.

THE U.S. National Research Council, acting as the Department of Science and Research of the Council of National Defence, has appointed a committee to investigate the fatigue phenomena of metals. Prof. H. F. Moore, of the engineering experiment station of the University of Illinois, is chairman. The committee is charged with the responsibility of developing a knowledge of the strength and durability of metals subjected to repeated stresses, such as ship structures, crank-shafts of aircraft engines, and heavy ordnance. It is expected that much of the experimentation required will be done in the laboratories of the University of Illinois at Urbana under the personal direction of Prof. Moore. 